\title{
ELECTRONIC TRANSPORT IN CUPRIC FERROCYANIDE ACTIVATED BY INTERSTITIAL WATER MOLECULES
}

\author{
K. TENNAKONE \\ Department of Physics, University of Rubuna, \\ Matara, Sri Lanka.
}

(Date of receipt: 22 January 1985)

(Date of acceptance: 17 April 1985)

\begin{abstract}
Coordinated and free interstitial water molecules in cupric ferrocyanide is found to excite electronic conduction with different activation energies. Theoretical argument is given to explain the observations.
\end{abstract}

\section{Introduction}

Ferrocyanides and ferricyanides of heavy metals form crystallinc solids of similar structure with interesting properties. 1, 2, 5, 6, 15 All these materials have face-centred cubic arrangement of metal cations at the corners of unit cubes linked by cyanide ions placed along the edges. In a ferrocyanide the carbon atom of $\mathrm{CN}^{-}$is coordinated to $\mathrm{Fe}^{2+}$ and the nitrogen atom is coordinated to the other metal ion. Ferricyanides have the samc type of bondings with $\mathrm{Fe}^{2+}$ replaced by $\mathrm{Fe}^{3+}$. A property arising from this structure is that the unit cells arc unusually large (lattice constant $\sim 10 \mathrm{~A}^{\circ}$ ) and as a result the crystal can accommodate forcign molecules, gencrally water as interstitial impurities. $1,2,4,5,6,7,15$ It is known that coordinated as well as free water molecules could exist within the interstices of prussian blue type of compounds. X-ray structural analysis indicates that the coordinated water molecules are located near the metal cations and the free water molecules gets hydrogen bonded to the coordinate ones. ${ }^{5}$ However, on thermodynamical grounds the author has argued that a small fraction of free water molecules could also get located within the ferro- or ferricyanide ions. ${ }^{10}$ The author and co-workers. $8,9,10,11,12,13$ have noted that most ferro- and ferricyanides exhibits electronic conduction in the presence of interstitial water with the following characteristics :

(1) Conductivity decrcases rapidly once a critical temperature $\mathrm{T}_{\mathrm{c}}(110-140 \mathrm{C})$ is exceeded.

(2) The thermal activation cncroy of charge carriers generally have the same order of magnitude $0.25-0.35 \mathrm{el}^{\prime}$ (Table 1) 
(3) Unless the concentration of free water molecules is largely in excess of the bound ones, the majority charge carriers in ferrocyanides are electrons and those in ferricyanides are holes (Table 1).

Table I

\begin{tabular}{|c|c|c|c|}
\hline Compound & $\mathrm{E}(\mathrm{eV})$ & $\mathrm{T}_{\mathrm{c}}$ & Type \\
\hline $\mathrm{Zn}_{2}\left[\mathrm{Fe}(\mathrm{CN})_{6}\right] \cdot 3 \mathrm{H}_{2} \mathrm{O}$ & 0.32 & 110 & $\mathrm{n}$ \\
\hline $\mathrm{Cd}_{2}\left[\mathrm{Fe}(\mathrm{CN})_{6}\right] \cdot \mathrm{xH}_{2} \mathrm{O}$ & 0.35 & 110 & $\mathrm{n}$ \\
\hline $\mathrm{Pb}_{2}\left[\mathrm{Fe}(\mathrm{CN})_{6}\right] \cdot 2.4 \mathrm{H}_{2} 0$ & 0.32 & 110 & $\mathrm{n}$ \\
\hline $\mathrm{Cu}_{2}\left[\mathrm{Fe}(\mathrm{CN})_{2}\right] \cdot 2 \mathrm{H}_{2} \mathrm{O}$ & 0.57 & 110 & $\mathrm{p}$ \\
\hline $\mathrm{Ho}_{4}\left[\mathrm{Fe}(\mathrm{CN})_{6}\right]_{3} \cdot 5 \mathrm{H}_{2} \mathrm{O}$ & 0.38 & 130 & $\mathrm{n}$ \\
\hline $\mathrm{Er}_{4}\left[\mathrm{Fe}(\mathrm{CN})_{6}\right]_{3} \cdot 5 \mathrm{H}_{2} \mathrm{O}$ & 0.36 & 130 & $\mathrm{n}$ \\
\hline $\mathrm{Yb}_{4}\left[\mathrm{Fe}(\mathrm{CN})_{6}\right] 3.5 \mathrm{H}_{2} 0$ & 0.39 & 130 & $\mathrm{n}$ \\
\hline $\mathrm{Eu}_{4}\left[\mathrm{Fe}(\mathrm{CN})_{6}\right]_{3} \cdot 5 \mathrm{H}_{2} \mathrm{O}$ & 0.39 & 128 & $\mathrm{n}$ \\
\hline $\mathrm{Gd}_{4}\left[\mathrm{Fe}(\mathrm{CN})_{6}\right]_{3} \cdot 5 \mathrm{H}_{2} \mathrm{O}$ & 0.39 & 142 & $\mathrm{n}$ \\
\hline $\mathrm{Zn}_{3}\left[\mathrm{Fe}(\mathrm{CN})_{6}\right]_{2} \cdot 5 \mathrm{H}_{2} \mathrm{O}$ & 0.27 & 117 & $\mathrm{p}$ \\
\hline $\mathrm{Cd}_{3}\left[\mathrm{Fe}(\mathrm{CN})_{6}\right] 2 \cdot 5 \mathrm{H}_{2} \mathrm{O}$ & 0.27 & 120 & $\mathrm{p}$ \\
\hline $\mathrm{Pb}_{3}\left[\mathrm{Fe}(\mathrm{CN})_{6}\right]_{2} \cdot \mathrm{xH}_{2} \mathrm{O}$ & 0.26 & 112 & $\mathrm{p}$ \\
\hline $\mathrm{Cu}_{3}\left[\mathrm{Fe}(\mathrm{CN})_{6}\right]{ }_{2} \cdot 12 \mathrm{H}_{2} \mathrm{O}$ & 0.23 & 118 & $\mathrm{p}$ \\
\hline $\mathrm{Cd}_{3}\left[\mathrm{Fe}(\mathrm{CN})_{6}\right]_{2} \cdot \mathrm{xH}_{2} \mathrm{O}$ & 0.25 & 122 & $\mathrm{p}$ \\
\hline
\end{tabular}

(4) Ferri- and Ferrocyanides with few molecules of coordinated water (e.g. lead ferrocyanide with two molecules of coordinate water) tend to exhibit electronic conduction only if free molecules water are also present. 
The author has shown that although it is thermodynamically more favourable for $\mathrm{H}_{2} \mathrm{O}$ molecules to get coordinated near the metallic ions a small fraction of ferro- or ferricyanide ions could also get hydrated. . $^{0}$ The hydrated ferrocyanide (ferricyanide) ions (Figure 1) donate (accept) electron to (from) the conduction (valence) band, $8,9,10,11,12,13$ i.e.,

\section{Figure 1}

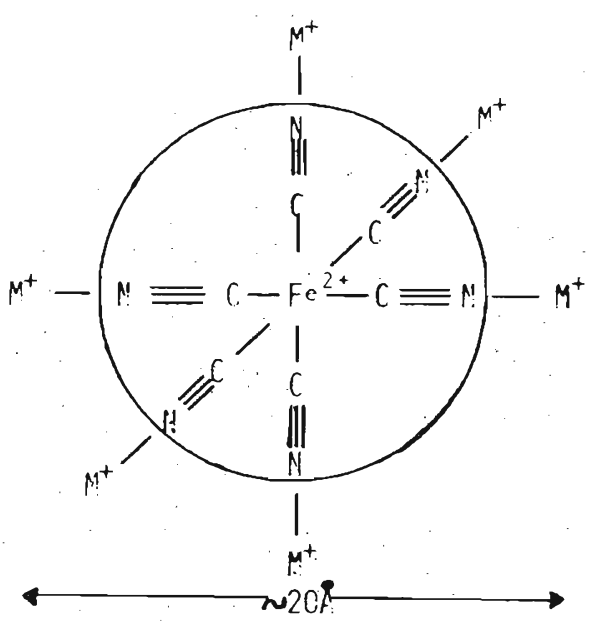

(a)

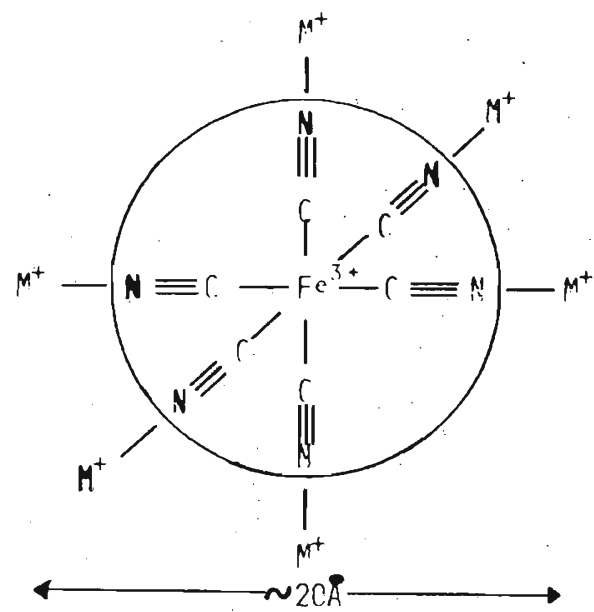

(b)

Figure 1. Diagrams showing the octahedral linkage of $\mathrm{CH}^{-}$ions into (a) $\mathrm{Fe}^{2+}$ ion in ferrocyanide (b) $\mathrm{Fe}^{3+}$ ion in a ferricyanide ( $\mathrm{M}^{+}$is a metal ion). When the spherical region denoted by the circle is filled with $\mathrm{H}_{2} \mathrm{O}$ molecules (a) and (b) behave as ferro- and ferricyanide ions in aqueous solution. 


\section{Ferrocyanides}

$\begin{array}{rlcc}\mathrm{Fe}(\mathrm{CN})_{6}^{4-} \quad \rightarrow \quad \mathrm{Fe}(\mathrm{CN})_{6}^{3-} & +\quad \mathrm{e} \\ & \downarrow \\ & \text { conduction band }\end{array}$

\section{Ferricyanides}

$$
\begin{gathered}
\mathrm{Fe}(\mathrm{CN})_{6}^{3-}+\quad \text { e } \rightarrow \quad \mathrm{Fe}(\mathrm{CN})_{6}^{4-} \\
\uparrow \\
\text { valence band }
\end{gathered}
$$

Because of hydration, the activation energies of these processes have same order of magnitude as the $\mathrm{Fe}(\mathrm{CN})_{6}^{3-} / \mathrm{Fe}(\mathrm{CN})_{6}^{4-}$ redox potential $(\sim 0.36 \mathrm{eV})$ and the hydrated ferri- and ferrocyanides behave as $n$ and $p$ type semiconductors. ${ }^{9} \quad$ At temperatures above $\mathrm{T}_{\mathrm{C}}\left(\mathrm{kT}_{\mathrm{C}} \sim 0.03 \mathrm{eV}\right)$ the bonds that bind $\mathrm{H}_{2} \mathrm{O}$ molecules break and effect disappears.

In this note we report our observations on electronic transport properties of $\mathrm{Cu}_{2} \mathrm{Fe}(\mathrm{CN})_{6} \cdot 2 \mathrm{H}_{2} 0$, that deviate significantly from the general pattern described earlier. In contrast to the other ferrocyanides we have examined, the thermal activation energy of this material is $\bumpeq 0.57 \mathrm{eV}$ and the major charge carriers are found to be holes. Theoretical arguments are given to explain the observations.

\section{Experimental}

Measurements were made with compressed pellets as well as single crystals. The material for making compressed pellets were made by the decomposition of copper sulphate with potassium ferrocyanide in the presence of dilute nitric acid (acid prevents the contamination of the product with cupric hydroxide resulting from hydrolysis). The precipitate was washed with deionized water and dried in vacuum at $40^{\circ} \mathrm{C}$. Chemical analysis confirmed that it corresponds to stoichiometric $\mathrm{Cu}_{2} \mathrm{Fe}(\mathrm{CN})_{6} \cdot 2 \mathrm{H}_{2} \mathrm{O}$. It was noted that unlike other heavy metal ferrocyanides the bound water molecules cannot be removed by prolonged drying in vacuum at temperatures below $110^{\circ} \mathrm{C}$. Thermal gravimetric analysis also indicated that the hydration number of the material is 2 (Figure 2). 


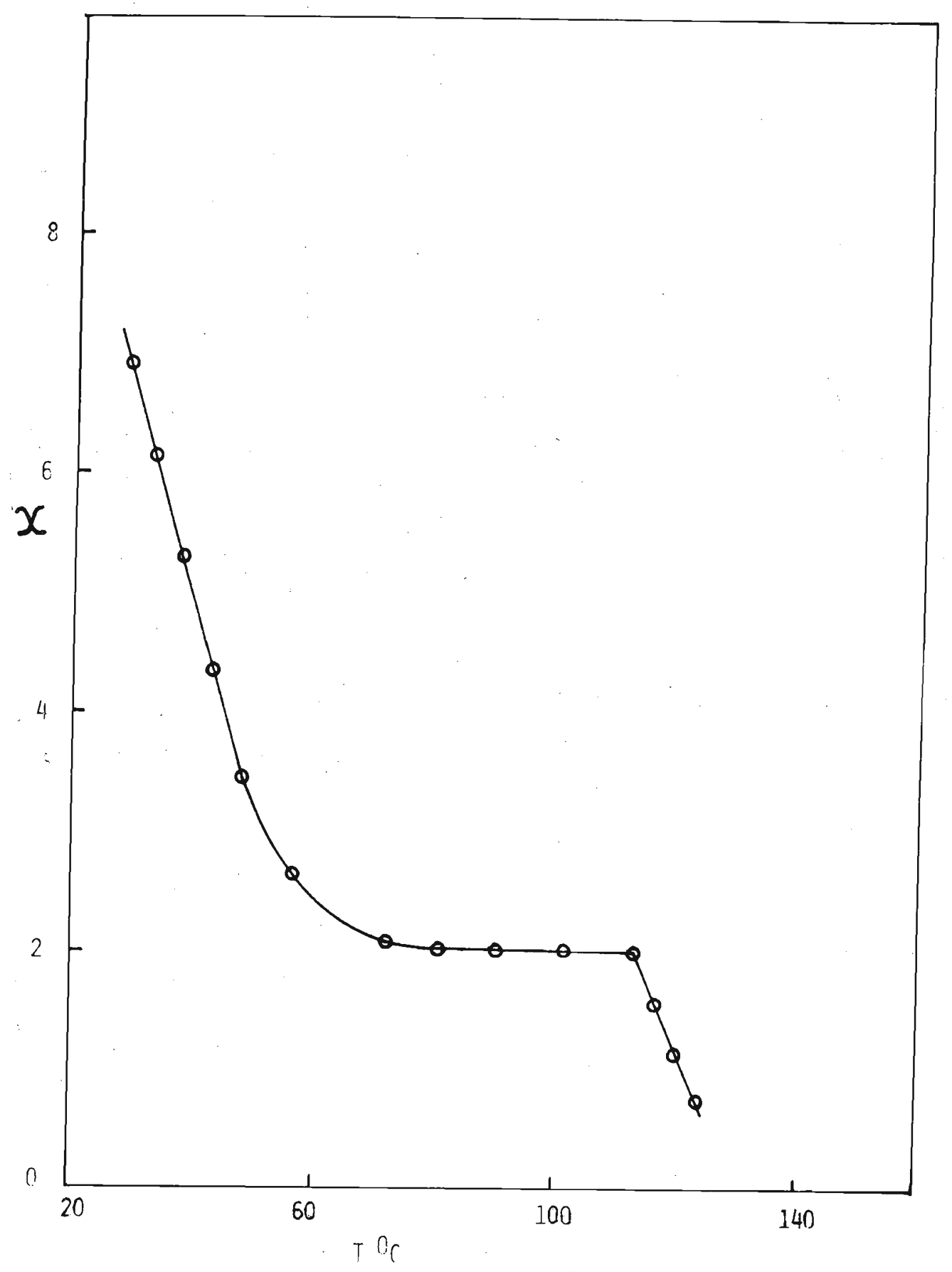

Fig. 2.

Figure 2. Thermal gravimetric analysis data for $\mathrm{Cu}_{2} \mathrm{Fe}(\mathrm{CN})_{6} \cdot \mathrm{xH}_{2} \mathrm{O}$. Plot of $\mathrm{x}$ vs $\mathrm{T}$ when heated at a constant rate $\left(2^{\circ} \mathrm{C} \mathrm{min}^{-1}\right)$. 
Single crystals of cupric ferrocyanide were prepared by diffusing very dilute solutions $\left(\sim 10^{-3} \mathrm{~mol} \mathrm{dm}^{-3}\right)$ of $\mathrm{K}_{4} \mathrm{Fe}(\mathrm{CN})_{6}$ and $\mathrm{CuSO}_{4}$ into a pellet of agar jelly ( $\sim 10 \mathrm{~cm}$ in length) at the middle of a glass tube (diameter $\sim 2 \mathrm{~cm}$ ) from opposite sides. Crystals $(\sim 2 \mathrm{mmx} 2 \mathrm{~mm} \times 2 \mathrm{~mm}$ ) were produced in a period of 6 months. The crystals were dried in vacuum at $40^{\circ} \mathrm{C}$ and pressed between stainless steel electrodes in glass tubes. The ends of the tube were sealed with epoxy resin, immersed in a thermostatic oil bath and the D.C. resistivity was determined using a bridge type resistance meter. The D.C. current-voltage characteristics were tested. Measurements were also carried out with samples where the concentration of $\mathrm{H}_{2} \mathrm{O}$ was in excess of the coordinated molecules. No significant differences were noted between the conductivity properties of single crystals and compacted pellets provided the pellets were made by compressing the powder to pressure exceeding $\sim 20 \mathrm{kbar}$.

We have not succeeded in devising methods for exact measurements of carrier mobilities. The sign of major charge carriers were determined from thermoelectric tests.

\section{Results and Discussion}

The plots of $\log \rho$ vs $\mathrm{T}^{-1}$ are indicated in Figure 3. In $\mathrm{Cu}_{2} \mathrm{Fe}(\mathrm{CN})_{6} \cdot 2 \mathrm{H}_{2} \mathrm{O}$ (Figure 3 Curve 1 ), it is seen that until a critical temperature $\mathrm{T}_{\mathrm{c}}=111^{\circ} \mathrm{C}$ is reached, $\rho$ decreases with $\mathrm{T}$ according to the relation,

$$
\rho=\rho_{\mathrm{O}} \mathrm{e}^{\mathrm{E} / \mathrm{kT}}
$$

with $\mathrm{E} \cong 0.57 \mathrm{eV}$ and $\rho_{\mathrm{O}} \cong 1.03 \times 10^{-3} \Omega \mathrm{cm}$. when $\mathrm{T}>\mathrm{T}_{\mathrm{c}}, \rho$ increases very rapidly with $\mathrm{T}$. The behaviour of samples containing water in excess of the two coordinated molecules is different. Figure 3, Curves 2 and 3 show the plots of $\log \rho$ vs $\mathrm{T}^{-1}$ when the water content corresponds to the approximate compositions $\mathrm{Cu}_{2} \mathrm{Fe}(\mathrm{CN})_{6} \cdot 2.4 \mathrm{H}_{2} \mathrm{O}$ and $\mathrm{Cu}_{2} \mathrm{Fe}(\mathrm{CN})_{6} \cdot 6 \mathrm{H}_{2} \mathrm{O}$ respectively. The characteristic feature of the Curve 2 is that it fits into two straight line portions with activation energies $\sim 0.30 \mathrm{eV}, \mathrm{T} \lessdot 72^{\circ}$ and $0.57 \mathrm{eV}, \mathrm{T}>72^{\circ} \mathrm{C}$. In the Curve 3 , where $\mathrm{H}_{2} \mathrm{O}$ concentration is much higher the activation energy remain constant at $\sim 0.3 \mathrm{eV}$ until a critical temperature is reached. D.C current-voltage characteristics are indicated in the Figure 4. Samples containing only coordinated molecules of water give linear plots (Figure 4 Curve 1). Here the charge carriers are entirely electronic and thermoelectric test show that the material is P-type. Figure 4 Curve 2 is the I-V characteristic for a sample with the approximate composition $\mathrm{Cu}_{2} \mathrm{Fe}(\mathrm{CN})_{6} \cdot 6 \mathrm{H}_{2} \mathrm{O}$. Here polarization effects are clearly evident and the shape of the plot suggests that three types charge carrierselectron holes and ions-are present. ${ }^{3,14}$ The ionic carriers are probably protons or $\mathrm{H}_{3}^{+} \mathrm{O}$ ions. 


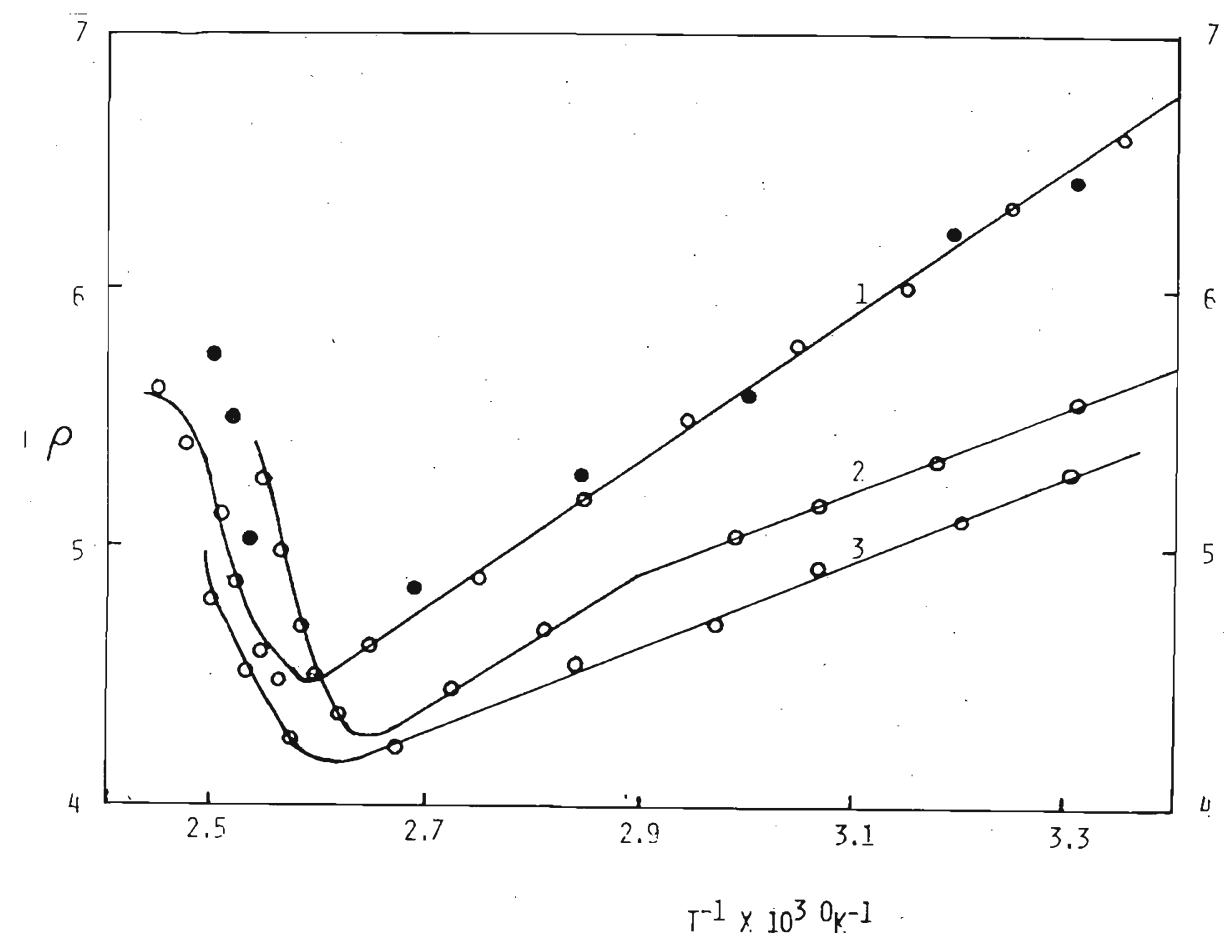

Figure 3. Plot of $\log \rho\left(\rho\right.$ in $\Omega \mathrm{cm}$ ) vs $\mathrm{T}^{-1}$ for $\mathrm{Cu}_{2} \mathrm{Fe}(\mathrm{CN})_{6} \cdot \mathrm{x} \mathrm{H}_{2} \mathrm{O}$ (1) $\mathrm{x}=2$ (2) $\mathrm{x} \simeq 2.4$ (3) $\mathrm{x}=6$ (o- single crystals, $\bullet-$ pellets).

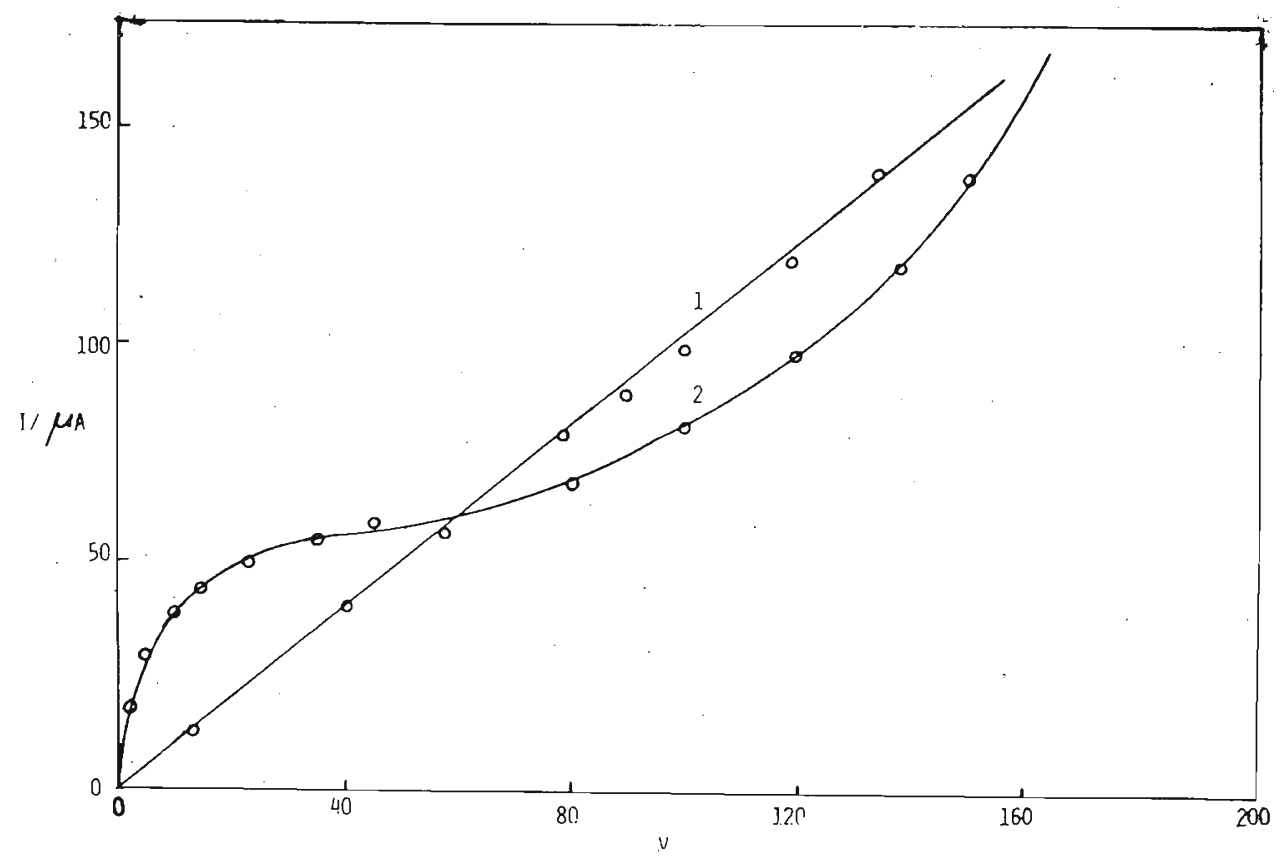

Figure 4. I - V characteristics for $\mathrm{Cu}_{2} \mathrm{Fe}(\mathrm{CN})_{6} \cdot \mathrm{x} \mathrm{H}_{2} \mathrm{O}(1) \mathrm{x}=2$ (2) $\mathrm{x} \simeq 2.4$ (3) $\mathrm{x} \simeq 6$ (measurements carried out with slices of crystals $\sim 2 \mathrm{~mm} \times 2 \mathrm{~mm} \times 2 \mathrm{~mm}$ ). 
It is not difficult to understand why electrical transport properties of cupric ferrocyanide is different from other ferrocyanides we have examined (Table 1). $\mathrm{Cu}^{++}$ion is a good electron acceptor. $\mathrm{Cu}^{++} / \mathrm{Cu}^{+}$redox potential in the crystal field is reduced by water molecules. Thus $\mathrm{Cu}^{++}$ion could accept electrons from the valence band. In other ferrocyanides (Table 1) the activation energy for a process similar to this at the metal cation is probably much higher. When excess water is present some of the ferrocyanide ions could also get hydrated and thus donate electrons to the conduction band with an activation energy $\sim 0.3 \mathrm{eV}$ as discussed earlier. If the concentration of excess water is small, it is natural to expect that the former process would predominate as the temperature increases. Thus the difference between the three curves in Figure 3 can be understood. Again the above hypothesis explains why both types of charge carriers appear when there is free interstitial water.

\section{Reference}

1. AYRES, J. B. \& WAGGONER, W. A. (1971) J. Inorg. Nuclear. Chem. $33: 721$

2. BONNETTE, A. K. \& ALlEN, J. F. Jr, (1971) Inorg. Chem. $10: 1613$

3. CHANDRA, S. (1981) Superionic Solids North-Holland, Amsterdam

4. GANGULI, S. \& BHATTACHARYA, M. (1983) J. Chem. Soc. Faraday. Trans. 79 : 1513

5. LUDI, A. \& GUDEL, H. U. (1973) Struct. Bonding 14 : 1

6. LUDI, A., GUdEL, H. U. \& RUEGG, M. (1970) Inorg. Chem. 9 : 2224

7. SHRIVER, D. F. \& BROWN, D. B. (1971) Inorg. Chem. 10: 1613

8. TENNAKONE, K. (1983) J. Chem. Pbys. 78(6): 3343

9. TENNAKONE, K. (1983) J. Pbys. C 16: L 1193

10. TENNAKONE, K. J. Solid State. Chem. (in press)

11. TENNAKONE, K. \& ARIYASINGHA, W. M. (1981) J. Chem. Phys. 74(8) : 4661

12. TENNAKONE, K. \& Dharmaratne, W. G. D. (1983) J. Phys. C. $16: 5633$

13. TENNAKONE, K. \& KAlUARACHCHI, D. (1980) Pbys. Stat. Solia). 58 : K55

14. WAGner, J. B. \& WAGNeR, C. (1957) J. Chem. Pbys. 26: 1597

15. WELLS, A. F. (1975) Structural Inorganic Chemistry, 4th ed. Clarendon Press, Oxford. 